\title{
Uji Aktivitas Antiplasmodium Dari Isolat Kulit Batang Kayu Tammate (Lannea coromandelica Houtt. Merr.) Secara In-Vitro
}

\author{
Karlina Amir Tahir*, Haeria, Alifia Putri Febriyanti, St. Chadijah, Nursalam Hamzah \\ Department of Pharmacy, Alauddin State Islamic University of Makassar
}

\begin{tabular}{|c|c|}
\hline Article info & Abstract \\
\hline $\begin{array}{l}\text { History } \\
\text { Submission } \cdot 24-1\end{array}$ & One of the main causes of death and a major public health problem is \\
\hline Submission: $24-12-2019$ & malaria. Some drug resistance and the limited number of effective drugs \\
\hline Review: $29-12-2019$ & have given the community a sense of worry. This makes the discovery of new \\
\hline Accepted: $22-02-2020$ & antimalarial compounds very necessary. Based on the results of exploration \\
\hline "Email: & of natural materials, Javanese wood is one of the plants that is efficacious \\
\hline karlina.amir@uin- & as an antimicrobial and is thought to be efficaclous as antiplasmodium. This \\
\hline alauddin.ac.id & $\begin{array}{l}\text { study was then conducted to find hexan and ethyl acetate isolates from the } \\
\text { Java wood fraction (Lannea coromandelica Houtt. Merr.) Which effectively }\end{array}$ \\
\hline DOI: $10.33096 /$ jffi.v7i1.591 & $\begin{array}{l}\text { inhibited the development of Plasmodium falciparum in vitro. This research } \\
\text { is a follow-up study from previous studies in testing the fraction of Javanese }\end{array}$ \\
\hline Keywords: & bark against antioxidant activity. The procedure starts from hexan and ethyl \\
\hline Lannea coromandelica; & acetate isolates with five concentrations of $10(\mu \mathrm{g} / \mathrm{ml}), 1(\mu \mathrm{g} / \mathrm{ml}), 0.1(\mu \mathrm{g}$ \\
\hline Antiplasmodium; & $/ \mathrm{ml}), 0.01(\mu \mathrm{g} / \mathrm{ml})$ and $0.001(\mu \mathrm{g} / \mathrm{ml}) 3 \mathrm{D} 7$ strain of Plasmodium \\
\hline Antimalaria; Plasmodium & falciparum was measured based on the average percent resistance. The \\
\hline falciparum & $\begin{array}{l}\text { results of this study indicate that etil asetat isolate have } I_{50} 2,727 \mu \mathrm{g} / \mathrm{ml} \text {, } \\
\text { its mean moderate activity as antiplasmodium. While hexan isolate have } \\
I C_{50}>10 \mu \mathrm{g} / \mathrm{ml} \text { its mean not have or low antiplasmodium activity. }\end{array}$ \\
\hline
\end{tabular}

\section{Pendahuluan}

Malaria adalah penyakit infeksi yang disebabkan oleh parasit plasmodium yang hidup dan berkembang biak di dalam sel darah manusia. Penyakit ini secara alami ditularkan melalui gigitan nyamuk anopheles betina (Direktur PPBB, 2014).

Artesunate, Amodiaquin, Primaquin digunakan untuk lini pertama falciparum tanpa komplikasi. Lini kedua yaitu Kina, tetrasiklin/doksisiklin dan primaquin. Untuk pengobatan malaria vivax/ovale yaitu pada lini pertama tablet klorokuin + tablet primakuin. Lalu pengobatan malaria vivax/ovale resisten klorokuin digunakan kina dan primakuin dengan pengaturan dosis yang sesuai. Namun beberapa jenis plasmodium dilaporkan mengalami banyak resistensi terhadap obat amodiaquin, primaquin maupun klorokuin (Putra, 2011).

Peningkatan kasus resistensi parasit malaria terhadap obat-obat yang digunakan masyarakat menjadi perhatian utama bagi peneliti. Kegagalan pengobatan bahkan kematian dapat terjadi karena resistensi plasmodium (WHO, 2016). Penyebab utama resistensi yaitu karena mutasipada gen-gen plasmodium. Hampir setengah dari populasi di dunia pada 100 negara dan wilayah berisiko malaria bahkan berbagai negara dikawasan Asia Tenggara. Ditahun 2018, Kementrian Kesehatan Republik Indonesia merilis prevelensi malaria berdasarkan riwayat pemeriksaan darah menurut provinsi. Dimana, untuk daerah endemik malaria yaitu Papua sebanyak 12\%, Papua Barat 9\%, NTT 2\%, Bengkulu 1,9\%, Maluku Utara 1,8\% dan daerah lain dibawah 1\% (Kemenkes RI, 2018). Sedangkan untuk resistensi falcifarum terhadap klorokuin telah ada sejak tahun 1973. Penelitian tahun 1998 di Kalimantan Timur mendapatkan 50\% pasien resistensi I, 19,6\% resistensi II dan 7,5\% resistensi III terhadap klorokuin pun sama dengan sulfadoksin-primetamin (Napoleon, 2009).

Resistensi plasmodium terhadap obat-obat sintetik tersebut memberikan artian bahwa perlunya ada penemuan obat baru sehingga mampu menggantikan dan menekan resistensi tersebut mengingat prevelensi malaria masih jauh dari angka yang diharapkan. Angka tersebut masih tergolong tinggi untuk daerah endemik, hal tersebut mendorong peneliti untuk berupaya mengurangi resistensi malaria tersebut dengan berusaha menemukan antimalaria baru, salah satunya melalui eksplorasi senyawa aktif dari bahan alam berupa tanaman obat yang dapat digunakan masyarakat untuk mengobati malaria diberbagai daerah endemik di Indonesia bahkan didunia.

Kayu jawa dalam masyarakat Sulawesi Selatan dikenal dengan sebutan "tammate atau aju jawa" merupakan tanaman yang biasanya dijadikan tanaman pagar, selain itu kayu jawa juga merupakan salah satu tanaman tradisional yang digunakan masyarakat sebagai obat (Rahmadani, 2015). Bagian yang sering digunakan masyarakat dalam pengobatan adalah kulit batang. Kulit batang (c) (†) () Copyright (C) 2020 Jurnal Fitofarmaka Indonesia. This is an open-access article distributed under the terms of the Creative Commons Attribution-ShareAlike 4.0 International License 
tanaman kayu jawa mengandung metabolit sekunder: Alkaloid, terpenoid, steroid, saponin, flavonoid, dan glikosida jantung (Wahid A. , 2012).

Berdasarkan penelitian sebelumnya Fraksi F1, Fraksi F2, Fraksi F3, Fraksi F4, Fraksi F5, Fraksi F6, dan juga Fraksi F7 masing-masing konsentrasi 100 ppm dilakukan pengujian terhadap Plasmodium falciparum strain 3D7 diukur berdasarkan persen hambatan rata-rata. Hasil penelitian ini menunjukkan bahwa semua sampel uji kulit batang kayu jawa mampu menghambat pertumbuhan dari Plasmodium falciparum dengan nilai persen hambatan berada diatas 30\%. Partisi dan Fraksi yang menunjukkan persen hambatan paling tinggi adalah Partisi larut heksan dengan nilai persen hambatan $89,50 \pm 0,77 \%$ dan Fraksi F2 dengan nilai 96,80 \pm $0,16 \%$ (Nursalam Hamzah, 2017). Melihat persen hambatan tersebut yang sangat berpotensi untuk disintesis menjadi senyawa baru dalam pengobatan antimalaria mendorong peneliti untuk membuatnya ketahap lanjutan yaitu pembuatan isolat. Hal inilah yang kemudian melatar belakangi dilakukan penelitian Isolasi Senyawa Aktif Kulit Batang Kayu Jawa (Lannea coromandelica) dan Uji Aktivitas Anti Plasmodium Sebagai Pengobatan Malaria.

\section{Metode Penelitian \\ II.1 Ekstraksi}

Bagian tanaman yang digunakan adalah kulit batang. Sampel diperoleh dari Kabupaten Gowa. Sampel dikeringkan dan diserbukkan. Serbuk kering kulit batang kayu jawa sebanyak $1800 \mathrm{~g}$ diekstraksi dengan metode maserasi menggunakan metanol $5000 \mathrm{ml}$.

\section{II.2 Partisi}

Partisi dilakukan dengan metode partisi cair-padat sebanyak 20,51 g menggunakan pelarut n-heksan sebanyak $1700 \mathrm{ml}$, sehingga diperoleh partisi larut heksan dan partisi tidak larut heksan.

\section{II.3 Fraksinasi}

Diperoleh fraksi hasil dari kromatografi cair vakum, dilarutkan lalu ditotol pada lempeng fraksi yang diperoleh, kemudian dielusi menggunakan eluen yang sesuai. Setelah itu diamati dibawah lampu UV $366 \mathrm{~nm}$ dan $254 \mathrm{~nm}$, dan didapatkan fraksi terbaik. Digabungkan fraksi yang memiliki noda yang hampir sama atau sama.

\section{II.4 Isolasi}

Hasil fraksinasi tersebut kemudian dilakukan proses pemurnian dengan menggunakan menggunakan metode KLT 2 dimensi.

\section{II.5 Uji Aktivitas Antiplasmodium}

Penelitian ini adalah penelitian kuantitatif yang dilakukan secara eksperimental dengan metode Desjardins, dengan mengukur inkorporasi dari hipoksantin oleh parasit. Pertumbuhan parasit diamati dari pemakaian isotop hipoksantin oleh metabolisme parasit yang tumbuh di dalam kultur Setelah kultur diinkubasi 60 jam dan pertumbuhan kultur sehat serta tidak terkontaminasi, ditambahkan $50 \mathrm{ml}$ campuran RPMI dan serum yang mengandung isotop sebesar $0,25 \mu \mathrm{Ci}$. Kultur dalam sumuran dicampur agar homogen, kemudian dimasukkan ke dalam candle jar untuk dikultur lagi selama 12 jam pada $37^{\circ} \mathrm{C}$ sehingga didapatkan masa inkubasi 72 jam. Selanjutnya, parasit dipanen menggunakan pemanenan sel semi-otomatik. Inkorporasi dari radiolabel ditentukan dengan Liquid Scintillation Analyzer. Data dari Metode schizont maturation test dan up take $3 \mathrm{H}$-hipoksantin dianalisis dengan mengukur persentase penghambatan pertumbuhan parasit. Konsentrasi penghambatan 50\% $\left(\mathrm{IC}_{50}\right)$ senyawa uji ditetapkan dengan analisis probit, berdasarkan hubungan log kadar senyawa uji dengan $\%$ penghambatan pertumbuhan parasit.

\section{Hasil Dan Pembahasan}

Hasil penelitian yang diperoleh dari pengujian aktivitas isolat kulit batang kayu jawa terhadap Plasmodium falciparum sebagai anti malaria dapat dilihat pada table 1, 2 dan 3 .

Tabel 1. Hasil Pengujian Antiplasmodium terhadap Plasmodium falciparum isolat 1

\begin{tabular}{ccccccc}
\hline $\begin{array}{c}\text { Konsentrasi } \\
(\boldsymbol{\mu g} / \mathbf{m l})\end{array}$ & $\mathbf{R}$ & \multicolumn{2}{c}{ \% Parasitemia } & \% Pertumbuhan & $\begin{array}{c}\text { \% } \\
\text { Hambatan }\end{array}$ & $\begin{array}{c}\text { \% Hambatan } \\
\text { rata-rata }\end{array}$ \\
\cline { 3 - 6 } Kontrol (-) & 1 & 0.91 & 6.8 & 5.89 & - & - \\
& 2 & 0.91 & 6.75 & 5.84 & - & \\
10 & 1 & 0.91 & 4 & 3.09 & 47.54 & 47.74 \\
& 2 & 0.91 & 3.95 & 3.04 & 47.95 & \\
1 & 1 & 0.91 & 4.74 & 3.83 & 34.97 & 34.44 \\
& 2 & 0.91 & 4.77 & 3.86 & 33.90 & \\
0.1 & 1 & 0.91 & 5.19 & 4.28 & 27.33 & 27.28 \\
0.01 & 2 & 0.91 & 5.16 & 4.25 & 27.23 & \\
& 1 & 0.91 & 5.81 & 4.9 & 16.81 & 16.71 \\
0.001 & 2 & 0.91 & 5.78 & 4.87 & 16.61 & \\
& 1 & 0.91 & 6.49 & 5.58 & 5.26 & 4.77 \\
\hline
\end{tabular}


Tabel 2. Hasil Pengujian Antiplasmodium terhadap Plasmodium falciparum isolat 2

\begin{tabular}{ccccccc}
\hline $\begin{array}{c}\text { Konsentrasi } \\
(\boldsymbol{\mu g} / \mathbf{m l})\end{array}$ & $\mathbf{R}$ & \multicolumn{2}{c}{ \% Parasitemia } & \% Pertumbuhan & $\begin{array}{c}\text { \% } \\
\text { Hambatan }\end{array}$ & $\begin{array}{c}\text { \% Hambatan } \\
\text { rata-rata }\end{array}$ \\
\cline { 3 - 6 } Kontrol (-) & 1 & 0.91 & 6.80 & 5.89 & - & - \\
& 2 & 0.91 & 6.75 & 5.84 & - & \\
10 & 1 & 0.91 & 3.49 & 2.58 & 56.20 & 56.61 \\
& 2 & 0.91 & 3.42 & 2.51 & 57.20 & \\
1 & 1 & 0.91 & 4.17 & 3.26 & 44.65 & 44.76 \\
& 2 & 0.91 & 4.13 & 3.22 & 44.86 & \\
0.1 & 1 & 0.91 & 5.01 & 4.10 & 30.39 & 30.35 \\
0.01 & 2 & 0.91 & 4.98 & 4.07 & 30.31 & \\
& 1 & 0.91 & 5.74 & 4.83 & 18.00 & 17.47 \\
0.001 & 2 & 0.91 & 5.76 & 4.85 & 16.95 & 7.64 \\
\end{tabular}

Tabel 3. Ringkasan hasil uji dan nilai $\mathrm{IC}_{50}$

\begin{tabular}{|c|c|c|c|c|c|c|c|}
\hline \multirow[t]{2}{*}{ No } & \multirow[t]{2}{*}{ Sampel } & \multicolumn{5}{|c|}{ Konsentrasi $(\mu \mathrm{g} / \mathrm{ml})$} & \multirow{2}{*}{$\begin{array}{c}\text { IC50 } \\
(\mu \mathrm{g} / \mathrm{ml})\end{array}$} \\
\hline & & 10 & 1 & 0.1 & 0.01 & 0.001 & \\
\hline 1 & Isolat 1 & 47.74 & 34.44 & 27.28 & 16,71 & 4.77 & $>10$ \\
\hline 2 & Isolat 1 & 56.61 & 44.76 & 30.35 & 17.47 & 7.59 & 2.727 \\
\hline
\end{tabular}

Malaria adalah penyakit infeksi yang disebabkan oleh parasit plasmodium yang hidup dan berkembang biak di dalam sel darah manusia. Penyakit ini secara alami ditularkan melalui gigitan nyamuk anopheles betina (Direktur PPBB, 2014).

Penelitian ini bertujuan untuk mengetahui aktivitas antiplasmodium pada isolat yang diperoleh dari ekstrak kayu jawa terhadap Plasmodium falciparum secara in vitro. Hasil uji aktivitas tersebut nantinya akan ditentukan isolat yang manakah yang memiliki aktivitas sebagai antiplasmodium berdasarkan nilai $\mathrm{IC}_{50}$ yang telah dihitung berdasarkan analisis probit. Penelitian ini menggunakan sampel kulit batang Kayu jawa, sering digunakan masyarakat sebagai obat tradisional untuk mengobati berbagai penyakit. Kayu jawa digunakan untuk luka, mengatasi memar, diare opthalmia, asam urat, keseleo dan disentri. Di Sulawesi selatan masyarakat menggunakan kulit batang kayu jawa sebagai obat luka, hal ini disebabkan kemampuan kulit batang kayu jawa sebagai antibakteri, antimikroba, antiinflamasi. Batang kayu jawa juga dapat menekan pertumbuhan bakteri atau mikroba patogen dan mencegah terjadinya infeksi pada luka sehingga kesembuhan luka dapat dipercepat, dan diduga memiliki kemampuan sebagai antiplasmodium.

Proses isolasi kulit batang kayu jawa diawali dengan sampel kulit batang kayu jawa yang telah kering diekstraksi menggunakan metode maserasi. Prinsip metode ini ialah penyarian dari suatu sampel dengan cairan penyari untuk menarik semua komponen senyawa yang terkandung. Pada pengerjaan ini dilakukan ekstraksi dengan memaserasi 1800 gram sampel kulit batang kayu jawa yang telah kering menggunakan cairan penyari metanol dan dibiarkan selama $\pm 3 \times 24$ jam dan dilanjutkan proses penyaringan agar didapatkan hasil sarian yang nantinya akan di pekatkan untuk mendapatkan ekstrak kental dan sisa sarian akan di di remaserasi kembali.

Hasil fraksinasi tersebut kemudian dilakukan proses pemurnian untuk mengetahui hasil fraksi tersebut bisa dikatakan isolat dengan menggunakan menggunakan metode KLT 2 dimensi. Seperti yang diketahui dalam studi fitokimia metode ini bertujuan untuk mengetahui kemurnian isolat,dengan ditampakkannya noda yang tunggal menggunakan eluen yang berbeda. Dari proses pemurnian didapatkan hasil masingmasing fraksi memiliki hasil noda yang tunggal dan hasilnya dapat dikatakan isolat. Hasil yang kemudian didapatkan pada proses pemurnian senyawa tersebut adalah fraksi kayu jawa larut hexan kode B4 dan fraksi kayu jawa larut etil asetat kode B4 masing-masing memiliki 1 noda. Dan digunakan sebagai sampel pada penelitian ini yang akan dilakukan uji antiplasmodium. Sampel inilah yang akan dibuat menjadi 5 konsentrasi yaitu 10 $\mu \mathrm{g} / \mathrm{ml}, 1 \mu \mathrm{g} / \mathrm{ml}, 0,1 \mu \mathrm{g} / \mathrm{ml}, 0,01 \mu \mathrm{g} / \mathrm{ml}$ dan 0,01 $\mu \mathrm{g} / \mathrm{ml}$ serta satu kontrol negatif.

Sebelum melakukan pengujian, terlebih dahulu kita membuat Medium lengkap dan medium tidak lengkap. Dimana pembuatan medium tidak lengkap dibuat dengan mencampurkan 10,4 gram RPMI-1640, 11,9 gram HEPES, 4,2 gram $\mathrm{NaHCO}_{3}$, 0,10 gram hiposantin dan 1,0 g gentamisin, lalu ditambahkan aqua DM sampai volume $2000 \mathrm{~mL}$. Larutan disaring dengan kertas saring berukuran pori $0,22 \mu \mathrm{m}$, dimasukkan ke dalam botol scot, disimpan pada suhu $4^{\circ} \mathrm{C}$. Medium ini diinkubasi dalam inkubator dengan suhu $37^{\circ} \mathrm{C}$ dan $\mathrm{pH} 7,3-7,4$ sebelum digunakan. RPMI (Rosewell Parla Memorial Institute) digunakan sebagai salah satu 
media yang menumbuhkan sel mamalia, terutama sel suspensi, contohnya sel limfosit manusia. Selain itu, media ini juga dapat digunakan untuk menumbuhkan sel hybrid. Sedangkan HEPES (4(2-hydroxyethyl) -1-piperazineethanesulfonic acid) merupakan zat penyangga kimia organik zwitterionic dan dikategorikan sebagai buffer yang baik untuk digunakan. HEPES tidak memiliki manfaat nutrisi bagi sel. Tujuan ditambahkan ke media semata-mata untuk menambah kapasitas buffering ketika kultur sel membutuhkan waktu yang lama di luar inkubator CO2. HEPES banyak digunakan dalam banyak reaksi biokimia dan sebagai zat penyangga dalam beberapa media kultur sel. Penambahan HEPES memberikan buffering tambahan ke media kultur sel pada $\mathrm{pH}$ 7,2 sampai 7,6. Sedangkan pembuatan medium lengkap dilakukan dengan mencampur medium tidak lengkap sebanyak $45 \mathrm{~mL}$ dengan albumax $5 \mathrm{~mL}$. karena medium lengkap adalah medium yang mengandung $10 \%$ albumax.

Metode pembiakan parasit dilakukan dengan metode Thawing (1976) dengan menggunakan candle jar untuk meminimalkan gas $\mathrm{O}_{2}$. Parasit tumbuh optimal pada kondisi gas $\mathrm{O}_{2}$ yang sedikit dan 5\% $\mathrm{CO}_{2}$ (Jensen, 2002). Sebanyak 2 sampel di uji yaitu isolat 1 (larut hexan) dan isolat 2 (larut etil asetat) dengan masing-masing 5 konsentrasi yang berbeda, 10, 1, 0,1, 0,01, dan 0,001 lengkap dengan penggunaan kontrol (-) yang akan dilakukan uji. Pada uji aktivitas antiplasmodium in vitro digunakan Plasmodium falciparum strain 3D7 yang sensitif terhadap klorokuin. Uji aktivitas dilakukan dengan cara melarutkan bahan uji dalam DMSO kemudian dibuat pengenceran dalam media RPMI sampai diperoleh konsentrasi akhir sebesar $10.000 \mu \mathrm{g} / \mathrm{ml}$. Pada larutan uji ditambahkan suspensi parasit dengan kadar parasitemia $\pm 1 \%$ dan hematokrit 5\%. Kultur diinkubasi selama 48 jam pada suhu $37^{\circ} \mathrm{C}$. Kultur kemudian dipanen dan dibuat sediaan lapisan darah tipis dengan pewarnaan giemsa 20\%. Selanjutnya dihitung persen parasitemia dan persen penghambatan pertumbuhan P. falciparum dengan menghitung jumlah eritrosit yang terinfeksi setiap 1000 eritrosit di bawah mikroskop.

Pewarnaan Giemsa merupakan tehnik standar untuk mewarnai parasite plasmodium penyebab malaria, selain itu tehnik ini juga digunakan dalam histologi karena mampu mewarnai kromatin, membran inti sel, metachromasia, dan komponel sel lainnya. Tinta Giemsa tersusun atas campuran pewarna eosin, methylene blue, dan methylene azure. Campuran methylene azure dan methylene blue akan membentuk eosinat yang membuat hasil pewarnaan menjadi lebih stabil.

Uji aktivitas antiplasmodium in vitro dilakukan terhadap isolat, hasil fraksi larut heksan dan partisi larut etil asetat dengan masing-masing 5 konsentrasi yang berbeda. Data persentase parasitemia, persentase penghambatan terhadap $\mathrm{P}$. falciparum strain 3D7 dengan masa inkubasi 48 jam terdapat pada Tabel 6 dan 7. Dari hasil perhitungan persentase parasitemia, selanjutnya dilakukan perhitungan persentase penghambatan pertumbuhan Plasmodium. Persentase penghambatan pertumbuhan Plasmodium dihitung dari persentase parasitemia dan kontrol negatif. Persen parasitemia awal menunjukkan 0,91 \%. Hasil menunjukkan persen parasitemia setelah inkubasi pada kontrol negatif mengalami peningkatan dari sebelumnya $0,91 \%$ menjadi $6,8 \%$ dan $6,75 \%$, sehingga persen pertumbuhan plasmodium adalah $5.89 \%$ dan $5.84 \%$. Pada kedua sampel uji menunjukkan persen parasitemia dan persen pertumbuhan lebih kecil dibandingkan pada kontrol negatif. Hasil pengolahan data pada tabel 4 bahwa rata-rata persen penghambatan untuk tiap larutan uji masing-masing konsentrasi pada isolat 1 yaitu $47.74 \%, 34.44 \%$. $27.28 \%$, dan $16.71 \%$ dan $4.77 \%$. sedangkan pada isolat 2 yaitu $56.61 \%, 44.76 \%, 30.35 \%, 17.47 \%$ dan $7.59 \%$. Kemudian dilakukan analisis antara konsentrasi uji terhadap persen penghambatan dengan menggunakan analisis probit log untuk mengetahui nilai $\mathrm{IC}_{50}$ atau konsentrasi bahan uji yang dapat menghambat pertumbuhan parasit sebanyak 50\% untuk mengetahui bagaimana aktivitas anti plasmodium isolat tersebut.

Menurut Koyono et, al. 2011 suatu fraksi ekstrak atau senyawa dinyatakan memiliki aktivitas yang tinggi bila $\mathrm{IC}_{50}<5 \mu \mathrm{g} / \mathrm{mL}$, moderat bila $10>$ $\mathrm{IC}_{50}>5 \mu \mathrm{g} / \mathrm{mL}$ dan tidak aktif (inaktif) bila $\mathrm{IC}_{50}>$ $10 \mu \mathrm{g} / \mathrm{mL}$. Menurut Jurnal (Filberta, dkk, 2014) Semakin rendah nilai $\mathrm{IC}_{50}$, maka akan semakin baik aktivitasnya.

Hasil $\mathrm{IC}_{50}$ yang didapatkan pada percobaan ini untuk isolat 1 (Hexan) $>10 \mu \mathrm{g} / \mathrm{mL}$ dan isolat 2 (Etil asetat) 2,727 $\mu \mathrm{g} / \mathrm{mL}$. Hasil tersebut menunjukkan bahwa isolat hexan tidak memiliki aktivitas atau sangat lemah terhadap anti plasmodium. Sedangkan untuk isolat etil asetat memiliki aktivitas tinggi terhadap anti plasmodium. Hal tersebut juga dapat dilhat dari data yang disajikan pada tabel hasil pengujian untuk isolat 1 pada \% penghambatan rata-rata ternyata tidak ada yang mencapai $50 \%$. Oleh karena itu nilai $\mathrm{IC}_{50}$ pada isolat 1 diatas $10 \mu \mathrm{g} / \mathrm{mL}$ yang menandakan bahwa isolat 1 tidak aktif pada konsentasi tertinggi 10 $\mu \mathrm{g} / \mathrm{mL}$. diduga isolat 1 mampu melakukan penghambatan ketika dilakukan penambahan konsentrasi diatas $10 \mu \mathrm{g} / \mathrm{mL}$.

Sebelumnya telah dilaporkan dalam penelitian Wahid (2012). Kayu jawa mengandung metabolit sekunder seperti Alkaloid, terpenoid, steroid, saponin, flavonoid, dan glikosida jantung (Wahid, 2012). Sedangkan pada penelitian (Alam, et.all, 2017) senyawa senyawa fenolik dan flavonoid yang terkandung dalam kayu jawa adalah Quersetin, Isoquersetin, Leukosianidin, leukodelpidin, morin, 
kaempferol, Asam gallat, Epigallocatesin Dyhidroflavonols (Tofazzal, 2000).

Derifat Flavonoid dan senyawa fenolik dalam kandungan kayu jawa memiliki aktivitas sebagai antiplasmodium yang telah dilaporkan dalam penelitian yang berbeda adalah senyawa quercetin, isoquercetin, kaempferol (Beroa, 2009), (Hassan, 2013), (Dondee, K. et al.,, 2016), (Rudrapal, 2017).

Dilaporkan dalam penelitian (Lusiana, 2009.) yang melakukan pengujian Antiplasmodium secara in vitro terhadap Plasmodium falciparum strain W2 yang resisten klorokuin dan Plasmodium falciparum yang sensitif klorokuin, senyawa yang aktif sebagai antiplasmodium diidentifikasi mengandung golongan senyawa Alkaloid.

Dalam penelitian (Kusumaningrum, 2016) yang melakukan pengujian antiplasmodium secara in vitro terhadap Plasmodium falciparum strain 3D7 menyatakan ekstrak yang aktif menghambat pertumbuhan Plasmodium falciparum di identifikasi mengandung golongan senyawa terpenoid.

Dalam penelitian (Ihsan, 2017) yang melakukan pengujian antiplasmodium secara in vitro terhadap Plasmodium falciparum strain 3D7 menyatakan partisi dan fraksi yang aktif sebagai antiplasmodium memiliki kandungan mengandung senyawa Alkaloid, Flavonoid, Fenolik, dan Terpenoid.

Mekanisme penghambatan terhadap plasmodium untuk golongan senyawa alkaloid telah dilaporkan dapat menghambat pertumbuhan parasit dengan menghalangi pertumbuhan parasit melalui transport intraseluler kolin, sejumlah karbon yang mampu mengkelasi kation seperti $\mathrm{Ca} 2+, \mathrm{Fe} 2+$, dan $\mathrm{Mg} 2+$ yang ada di dalam parasit. Kelasi kation ini menghalangi sejumlah proses sintesis asam nukleat karena enzim ribonukleotida reduktase membutuhkan logam transisi sebagai kofaktor (Hilou, 2006). Kemudian pada senyawa golongan terpenoid juga telah diketahui dapat menghambat pertumbuhan Plasmodium dengan cara menghambat sintesis protein pada sel mamalia dan juga parasit malaria (Pouplin, 2007). Sedangkan pada senyawa golongan Flavonoid sebagai antiplasmodium memiliki mekanisme menghambat jalur permeasi baru (NPP) pada membran eritrosit yang terinfeksi plasmodium serta mekanisme lain yang belum diketahui (Widyawaruyanti, et al., 2011).

\section{Kesimpulan}

Berdasarkan hasil penelitian maka dapat disimpulkan bahwa Isolat etil asetat kulit batang Kayu Jawa (Lannea coromandelica Houtt. Merr.) memiliki aktivitas sangat aktif sebagai antiplasmodium, sedangkan isolat heksan kulit batang Kayu Jawa (Lannea coromandelica Houtt. Merr.) tidak memiliki aktivitas sebagai antiplasmodium. Nilai $\mathrm{IC}_{50}$ pada isolat yang memiliki aktivitas sebagai antiplasmodium yaitu 2.727 pada isolat 2 (Isolat etil asetat)

\section{Ucapan Terima Kasih}

Penghargaan kepada UIN Alauddin atas bantuan Hibah Penelitian Pembinaan Kapasitas/Kapasitas Pemula tahun 2018.

\section{Daftar Pustaka}

Alam, et.all. (2017). Lannea coromandelica (Houtt.) Merr. Induces Heme Oxygenase 1 (HO-1) Expression and Reduces Oxidative Stress via the p38/c-Jun N-Terminal KinaseNuclear Factor Erythroid 2-Related Factor 2 (p38/JNK-NRF2)-Mediated Antioxidant Pathway. International Journal Molecular Science, 18(266), 1-18.

Beroa, J. F.-L. (2009). Antimalar ial compounds isolated from plants used in traditional medicine. Journal of Pharmacy and Pharmacology, 61(11), 1401-1433.

Dondee, K. et al.,. (2016). The protective effect of Moringa oleifera leaf extract on liver damage in mice infected with Plasmodium berghei ANKA. Journal of Coastal Life Medicine, 4(9), 742-746.

Desjardins, R. C. (1979). Quantitative assessment of antimalarial activity in vitro by a semiautomated microdilution technique. Antimicrobial Agents Chemother, 16(6), 710-718.

Direktur PPBB. (2014). Pedoman Manajemen Malaria, Direktorat Jenderal Pengendalian Penyakit dan Penyehatan Lingkungan,. Jakarta:: Departemen Kesehatan Republik Indonesia.

Hassan, S. V. (2013). Activity Guided Isolation and Characterization of Antiplasmodial Agents of some Local medicinal Plants. Nigerian Journal of Basic and Applied Science, 21 (3), 177-185.

Kusumaningrum, N. A. (2016). Skripsi Uji Aktivitas Antimalaria Daun Helianthus annus L. dengan Ekstraksi Bertingkatterhadap Plasmodium falciparum secara In Vitro. Surabaya: Fakultas Farmasi Universitas Airlangga Departemen Farmakognosi dan Fitokimia.

Lusiana, H. (2009.). Skripsi Isolation and In Vitro Antiplasmodial Test of Alkaloid Compounds from Albertisia papuana Becc. Bogor: Institut Pertanian Bogor.

Napoleon, S. N. (2009). Efikasi Obat Kloroquin, Kina, Artesunat-SP, ArtesunatAmodiquine, Artesunat-Lumafentrin. 418.

Nursalam Hamzah, N. W. (2017). Growth Inhibition of Plasmodium falciparum and Micobacterium . Journal of Pharmaceutical and Medicinal Sciences, 85-90. 
Rudrapal, M. \&. (2017). Plant Flavonoids as Potential Source of Future Antimalarial leads. Journal in the field of Pharmacy, 8(1), 13-18.

Tofazzal, M. \&. (2000). Dihydroflavonols from Lannea coromandelica. Phytochemistri, 54(8), 901-90.

Wahid, A. (2012). In Vitro Phytochemical and Biological Investigation of Plant Lannea coromandelica (Famili: Anacardiaceae). Bangladesh: Thesis to Departemen Pharmacy East West University.

WHO. (2016). Malaria. Indonesia: Kemenkes. 